\title{
Toward Most Valuable City Logistics Initiatives: Crowd Logistics Solutions' Assessment Model
}

\author{
Jagienka Rześny Cieplińska ${ }^{1}$, Agnieszka Szmelter-Jarosz²
}

Submitted: 5.12.2019. Accepted: 15.06.2020

\section{Abstract}

Introduction: Crowd logistics is a widely accepted concept in times of the growing popularity of sharing economy solutions. The popularity of e-commerce and a tendency to provide same-day delivery are the main reasons for their development. Developing those trends requires new products and services, now available on the market, known in the transport area as crowd logistics solutions.

Purpose: The purpose of the paper is to provide a tool for assessing crowd-logistics solutions, taking into consideration customers' requirements. The text includes groups of environmental, economic, and social criteria to facilitate the choice of the best crowd logistics solution for freight transport.

Methodology: The research is based on the critical analysis of different sources (literature, European Commission reports, other reports and analyses) and practical solutions in the field of crowd logistics. The main data analysis method is the Analytic Hierarchy Process, usually used to evaluate variants in decision-making processes. This method was chosen because of the variety of data types (quantitative and qualitative) and formats, its popularity, universality, and replicability.

Results: This paper contains ready-to-use weights for the assessment of crowd logistics solutions. The proposed set of criteria and weights can be a useful tool for customers to evaluate the sharing-economy services landscape in the areas they manage.

Keywords: crowd logistics, city logistics, sharing economy, urban freight, MDCM, AHP

JEL: 041

1 WSB University in Gdańsk, 238a Grunwaldzka St., 80-266 Gdańsk, Poland; e-mail: jrzesny@wsb.gda.pl; https://orcid.org/0000-0002$-8882-8472$.

2 University of Gdańsk, Armii Krajowej 119/121, 81-824 Sopot, Poland; e-mail: agnieszka.szmelter-jarosz@ug.edu.pl; https://orcid.org/0000$-0002-6183-6114$. 


\section{Introduction}

Cities are real drivers of economic development, mostly by providing infrastructure, supporting activities, and offering services. Currently, about $52 \%$ of the world's population lives in cities, although it is estimated that this level will reach $67 \%$ by 2050 (United Nations, 2014). The urbanization and population growth, the fast development of e-commerce, and the growing expectation of customers require new, innovative solutions to ensure effective, social-friendly, and sustainable transportation within the cities (Cheba and Saniuk, 2016). Their evolution into metropolitan areas arises and develops as a result of complicated relations between economic and non-economic organizations (local authorities, local businesses, big companies) and the society (Cheba and Saniuk, 2016). In this context, city areas had to face an increasing demand for different types of mobility.

All transport operations in the cities experience problems related to transport policy, customer service, and above all, traffic flows, which are considered to have a negative economic impact (Buldeo Rai et al., 2017). In order to solve the problems of city transport systems and all related issues, many innovative solutions and initiatives are currently introduced. Most of them focus either on passengers or freight flows (Wang et al., 2016; Buldeo Rai et al., 2017; Devari et al., 2017; Buldeo Rai et al., 2018). They are treated separately due to the lack of a holistic and comprehensive view. The growing interest in shared passenger and freight transportation practices indicate that a significant opportunity could be in combining both (Buldeo Rai et al., 2017). Such applications can also be met and are widely described in various European Commission reports, most often in regards to sustainable urban mobility plans (SUMPs) with respect to a sustainable approach to urban management problem-solving (Un-Habitat, 2013; Gonzales-Feliu et al., 2018, Serafini et al., 2018).

The main aim of the paper is to provide a ready-to-use set of criteria for use in the Analytic Hierarchy Process (AHP) analysis of crowd logistics (CL) solutions according to up-to-date research results from the scientific literature. The structure of the paper is as follows. First, the literature review presents the origin and main characteristics of CL solutions. Then, the methodology of research is described, followed by the research results containing the weights of important identified criteria for assessing CL solutions. The last part of the paper concludes the results and discusses future research directions. 


\section{Literature Review}

\section{Crowdsourcing Essentials}

Crowdsourcing refers to the global sharing economy, which stems from an economic system based on sharing underused assets or services for free or for a fee (Botsman, 2013). In fact, the idea of sharing is neither new nor contemporary, because already the nineteenth-century English mathematician and engineer - Charles Babbage - hired a crowd to assist in computing astronomical tables (Babbage, 1832; Mladenow, 2016). The rise of the sharing economy makes it possible to monetize goods and services not deemed as assets before (Eckhardt and Bardhi, 2015). Consequently, new models emerged based on access to rather than ownership of assets (Hamari, 2016; DHL Trend Research, 2017). The sharing economy can be broadly divided into three categories (Schor, 2014):

- the recirculation of goods,

- the increased utilization of assets,

- the sharing of productive assets.

Sharing economy is treated as an umbrella term of collaborative consumption (Botsman and Rogers, 2010; Frenken and Schor, 2017; Carbone et al., 2018), crowdsourcing (Howe, 2006; Poetz et al., 2012), and assets-based consumption (Carbone et al., 2016). It contains new forms of distributed production or consumption with the help of new technology and brings people together in new ways (Afuah and Tucci, 2013; Carbone et al., 2018). Crowdsourcing was popularized by Howe (2006) and, according to his approach, it is a kind of an outsourcing strategy in which a company places an open call on an undefined group of people (the crowd) to perform a task that could be conducted without the company (Howe, 2006); the term itself derives from the words "crowd" and "outsourcing." The crowd is defined as a mass of people while outsourcing describes the shifting of processes, functions, and duties to third parties.

Today, the strength of sharing economy relies on the Internet and new technologies. (Schor, 2014; Mladenow, 2016).

\section{Characteristics of Crowd Logistics (CL)}

The most common examples of the sharing economy applied in cities are the energy mix, offices, parking sites, warehouses, flows of goods, knowledge, and data (Dasen et al., 2013). However, one of the most important areas is mobility, so among the various types of crowdsourcing initiatives many are related to logistics. According to prior research 
(Carbone et al., 2016; Carbone et al., 2018), four types of crowdsourcing initiatives can be distinguished in logistics:

- peer-to-peer logistics,

- business logistics,

- open logistics,

- crowd logistics.

Peer-to-peer logistics is related to the individuals who exchange, give, share goods or services, or organize the necessary physical operations themselves (Carbone et al., 2018). The role of a web platform is just informational because users interact directly with each other without intermediation by a third party.

Business logistics can be treated as a traditional solution within crowdsourcing initiatives. The platforms that promote such solutions take control and responsibility for managing physical flows to operationalize exchanges between peers (Carbone et al., 2016). Business logistics organizes indirect physical flows between peers in the consumer to business to consumer type.

Open logistics contains solutions enabling individuals to regain control of logistics chains related to the supply and distribution of goods (Carbone et al., 2016). Such initiatives are particularly common in the food area and can operate through non-profit structures, which allow their members - both consumers and farmers - to manage the whole supply chain.

The logistics aims at delivering goods and information to the right customers, at the right place, and at the right time. The concept of crowd logistics is a valuable candidate to contribute toward these objectives (Doan, 2011; Rouges et al., 2014; Mladenow, 2015). Crowd logistics is alternatively called crowd shipping, crowdsourced delivery, cargo hitching, or collaborative delivery (Buldeo-Rai et al., 2017). In peer-to-peer logistics, business logistics, and open logistics, logistics' role is supporting, while in crowd logistics, logistics is the actual purpose of crowdsourcing initiative (Carbone et al., 2016). Within crowd logistics initiatives, an online platform is used to sell logistics services provided by individuals, while its role is essential to enable individuals' logistics resources to be shared and optimized (Carbone et al., 2018).

The concept of crowd logistics comes from the sharing economy or resource sharing, and it refers to collaborative consumption made by the activities of sharing and exchanging of resources without owning the goods (Mehmann et al., 2015). Crowd logistics is 
a concept of sharing in transportation that aims to improve efficiency and sustainability of how objects are moved, stored, supplied, and utilized across the world by applying concepts from Internet data transfer to real-world shipping processes. Moreover, crowd logistics relies on Internet connectivity because technology enables passengers to use the capacity in their vehicles more efficiently by carrying parcels for others (Buldeo Rai et al., 2018). According to a comprehensive approach, several conditions within crowd logistics concept must be fulfilled: technological infrastructure, free capacity, crowd network, compensation, voluntary character (Sampaio et al., 2017).

The most accepted and complex definition of crowd logistics says that it "designates the outsourcing of logistics services to a mass of actors, whereby the coordination is supported by technical infrastructure" (Mehmann et al., 2015). According to this approach, the main aim of crowd logistics is to achieve the economic benefits for all stake - or shareholders. Crowd logistics initiatives can be applied within different crowdsourced services. According to the research results (Sampaio et al., 2019), the main identified types of CL services may be distinguished into two groups:

- crowdsourced delivery dedicated to freight deliveries:

- door-to-door deliveries,

- store-to-door deliveries,

- cargo-hitching services, in which the spare capacity of public transport is used for freight transportation.

According to the research conducted by Carbone et al. (2016) on 57 CL initiatives, we can distinguish four types of CL:

- crowd local delivery,

- crowd freight shipping,

- crowd freight forwarding, and

- crowd storage.

Each kind of service above is responsible for creating various types of logistics value. Crowd local delivery is based on the crowd's resources like cars, vans, or bikes and relies on making use of individual capabilities such as driving, picking up goods and delivering (Han et al., 2008). Crowd freight shipping offers shipping services but in a broader perspective: in the whole country or continent. The basis of these services also relies on the crowd's transport resources, mainly road vehicles like cars and vans. Crowd freight forwarding is based on other resources related to individual mobility to make products that are unavailable in one country become economically accessible. The added value 
of crowd storage lies in property resources possessed by the crowd, like garages or cellars. Thus, crowd storage offers local storage services for the city inhabitants.

Most popular proposed solutions are (Sampaio et al., 2017):

- services for people mobility,

- services for freight delivery,

- cargo-hitching services (Li and Hensher, 2013).

It is very important to highlight that pure crowd logistics activity should use existing flows; it is one of the necessary conditions of this phenomenon. If existing flows are used for the fulfillment of services, this will contribute to more sustainable city logistics (Marcucci et al., 2017; Primentel et al., 2018). However, many popular platforms, especially for people transportation, operate as on-demand transportation services, thus the fulfillment happens by creating new service rather than exploiting existing ones. Taking into consideration the fact the freight transport and express delivery are some of the fastest-growing subsectors in urban transport (Kafle et al., 2017; Buldeo Rai et al., 2018), and the number of vehicles for freight transport in city areas grows exponentially (Paloheiomo et al., 2016; Devari et al., 2017; Macharis, 2018), we focus on services for suburban and urban freight deliveries.

\section{Methodology}

\section{Sustainability Criteria}

All logistics activities that happen in city areas should be adapted to the requirements of sustainable development. According to the 1980 World Conservation Strategy (World Conservation Strategy, 1980), the concept of sustainability was defined as a development that would allow ecosystem services and biodiversity to be sustainable (IUNC, 1980). Then, the Brundtland Report in 1987 described sustainability further as "a kind of a development that meets the needs of the present without compromising the ability of future generation to meet their own needs" (Kebble, 1980). During the UN Conference on Environment and Development in Rio in 1992, sustainability was finally defined as a multidimensional concept consisting of three pillars (Drexhage and Murphy, 2010; Valiantis, 2016):

- social equity,

- economic growth, and

- environmental protection. 
Considering sustainable development as a three-dimensional notion, the question may be raised if all of them provide equal support or if there is a hierarchy of values among them. International organizations and institutions emphasize the need for protecting the environment as an essential prerequisite for social justice and economic development. However numerous researchers determined the sustainability criteria relating to environmental performance, the other two sustainability components - economic and social performance - require further consideration in an integrated and hierarchic manner (Buys et al., 2005; Dassen et al., 2013). The provision of clean water, clean air, or productive and clean land is foundational to a well-organized and responsible socioeconomic system. Moreover, it would be difficult to imagine a sustainable society without a sustainable production environment that provides a resource base. Similarly, a stable economy depends on the sustainable flow of materials, energy, and environmental resources; without them, economic systems will collapse (Morelli, 2011; Ekins, 2011; Moldan et al., 2014).

The model of crowd logistics solutions optimization follows sustainability criteria related to environmental, economic, and social performance (see Figure 1). As a result of present worldwide population growth, urbanization, and suburbanization trends - including urban sprawl - the necessity of sustainable approach for crowd logistics initiatives should stem from the need to protect the environment, develop the economy, and support the society, providing the foundation of trifold approach (Dink, 2005; Hopwood et al., 2005).

\section{Research Procedure}

Our research procedure was organized in two steps. First, we prepared the literature review to identify the main criteria for assessing the sustainability of sharing economy solutions, including crowd logistics. It was impossible to analyze only papers about the CLs' sustainability because of their very low number. Therefore, after a few literature search iterations, the final literature search was based on the sustainability of all the freight logistics initiatives within the sharing economy solutions in urban areas. Second, the method for criteria assessment was chosen and applied to calculate final weights for the criteria identified in the first step.

I used one set of keywords in the search for literature. The chosen procedure was the one developed in 2003 by Tranfield, Denyer, and Smart, dedicated to social sciences and widely used in economics and management-related literature reviews. The search strategy was based on keyword search ${ }^{3}$ in abstracts of papers in five scientific search engines:

In literature search, I employed the following notions: "sharing economy," "urban," "city," "freight transport," and "crowd." Full-text records from 2008 to 2019. Date of generating the literature base: 11.09.2019. 
DOAJ, EBSCOhost, SCOPUS, ScienceDirect, and Springer. Duplicates were eliminated with the Mendeley Desktop tool, then abstracts were analyzed to discern the papers related to the topic of the research and the final base for full-text analysis was determined (the rejected papers were mostly related to advanced mathematical models for traffic and transport routes).Within this step, 28 papers were analyzed and only 13 of them - those which indicated the sustainability criteria and the assessment of customers' viewpoint - were included in the final review. Some of the papers were only partly related to environmental criteria but were still very helpful to prepare the full list of criteria. Finally, 20 criteria were identified (see Figure 1 and Table 1), including six environmental (1-6), seven social (7-13) and seven economic (14-20). For each of them, the relation to others was discovered according to the research results found in the final review, as was also the way to measure or assess them.

\section{Figure 1. Research framework}

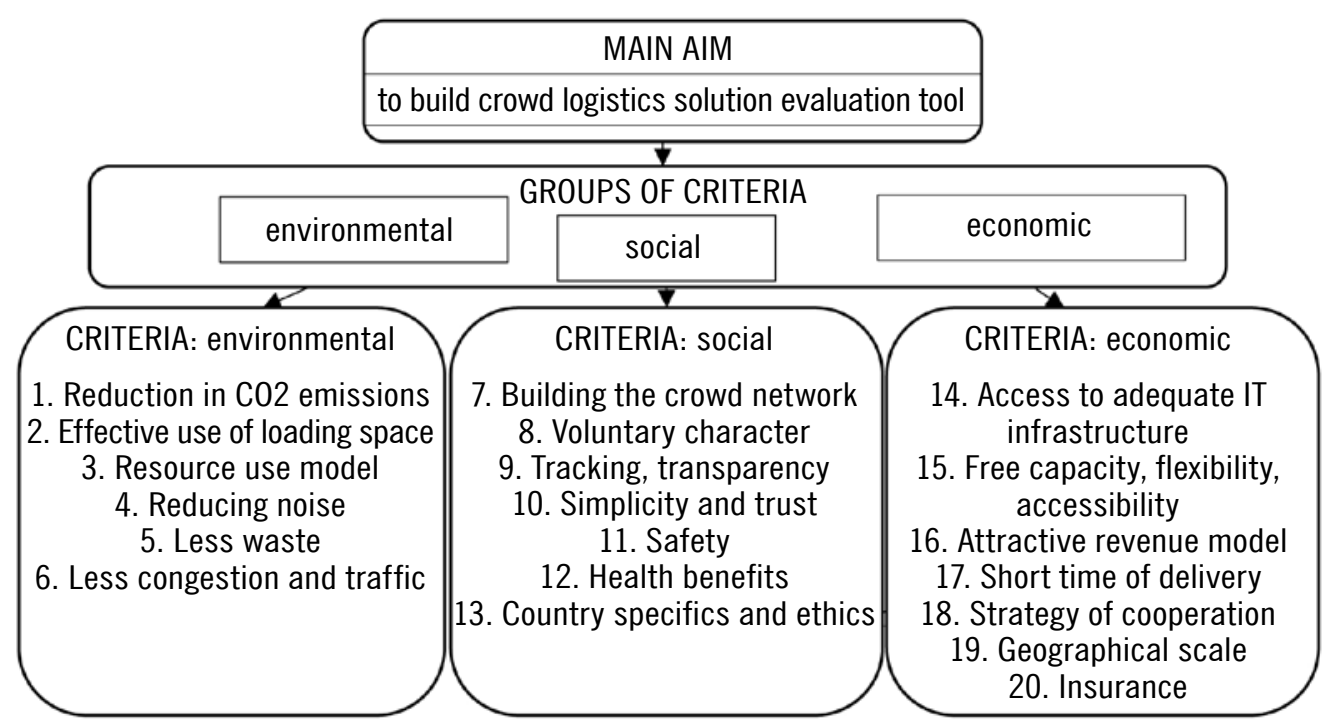

Source: own elaboration.

In the second part of the research, we needed a method for data analysis. Because the criteria were not quantitative but qualitative, while in the identified papers appeared different methods and scales, the method for this analysis had to allow for the assessment of the criteria in a flexible manner. Therefore, the AHP method was evaluated as the most popular for multi-criteria decision-making (MDCM), so we selected part of the AHP method for this study. The others like TOPSIS, DEMATEL, ELECTRE (I-IV), or PROMETHEE (I-IV) would also be appropriate (to some extent) for such an analysis, but we first made the short literature search procedure to identify the most popular 

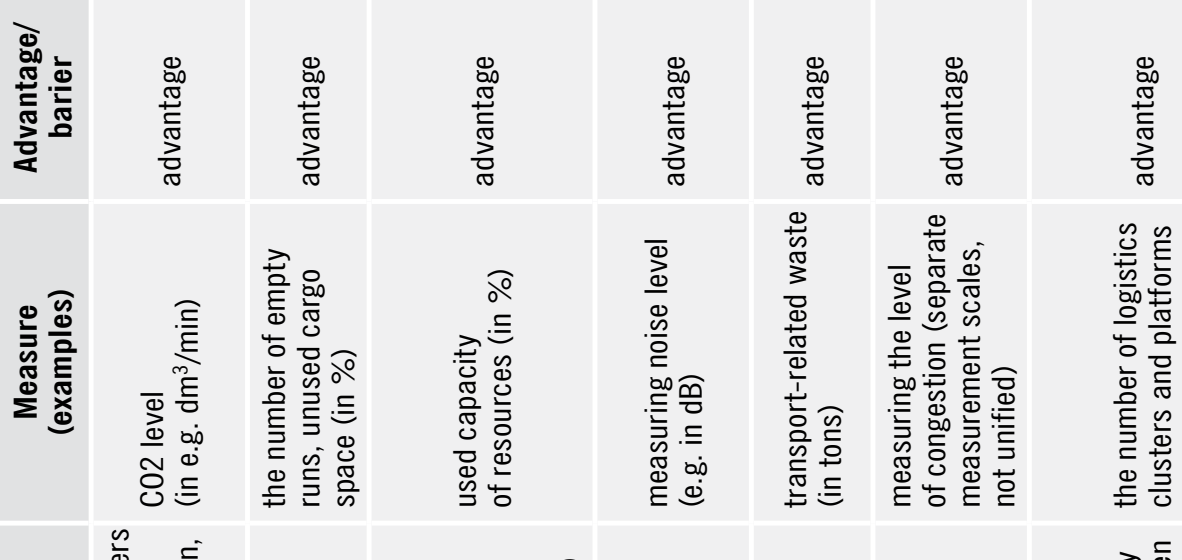

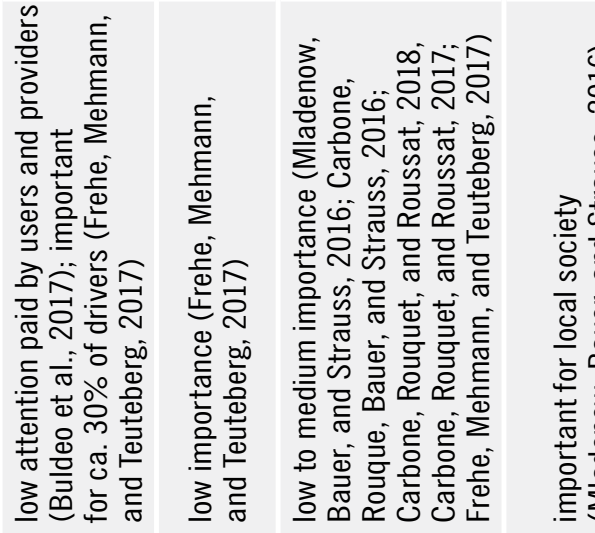

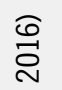

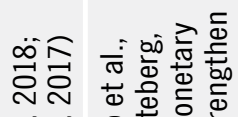

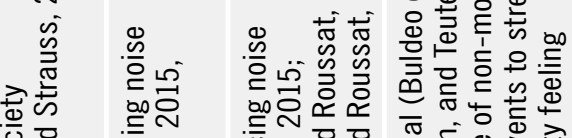

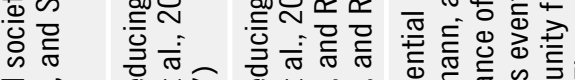

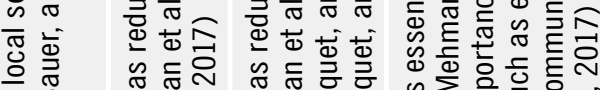

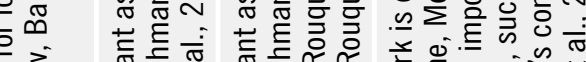

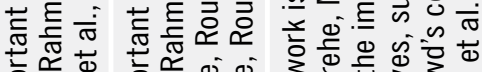

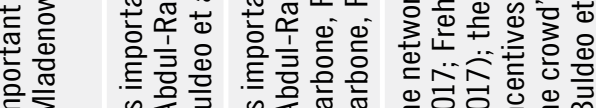

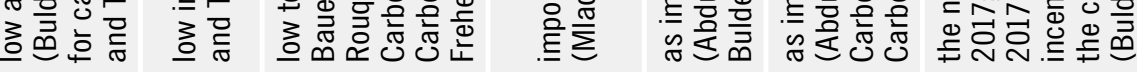

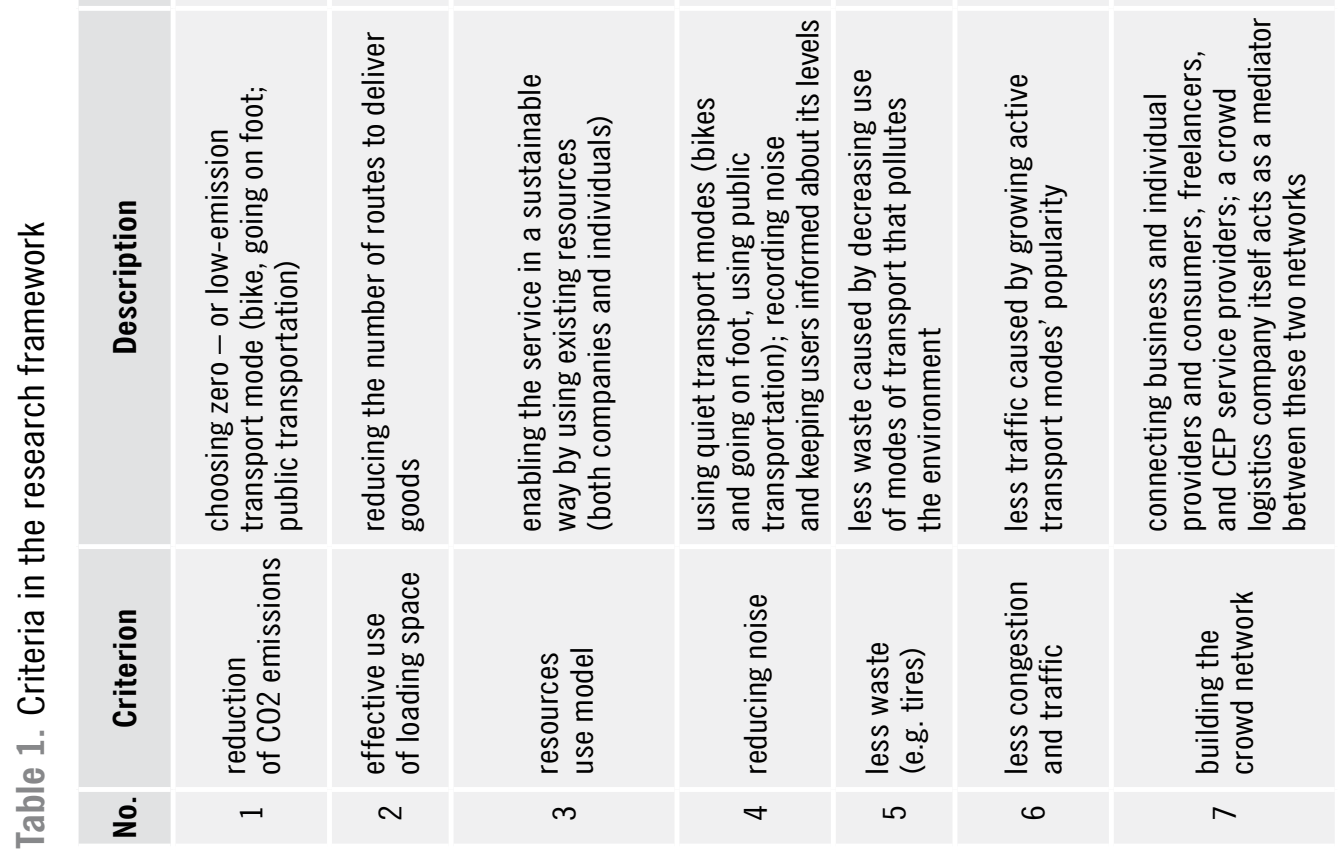




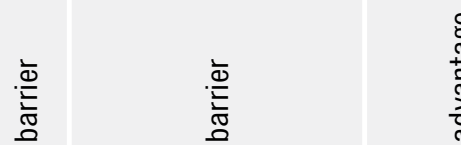

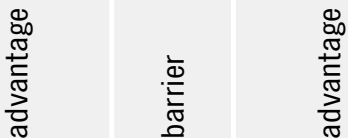

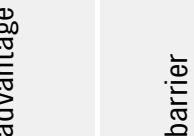

$\frac{\sqrt{2}}{\frac{10}{2}}$

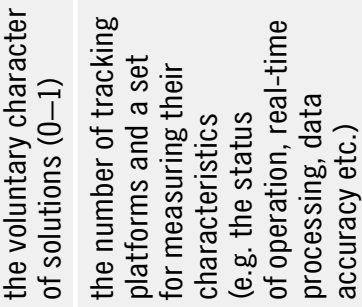

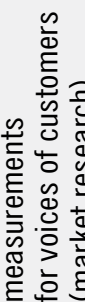

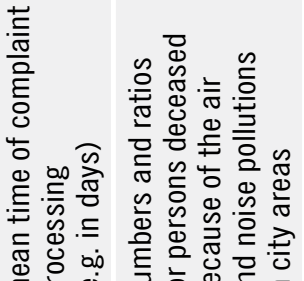

它 을

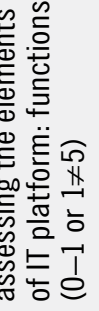
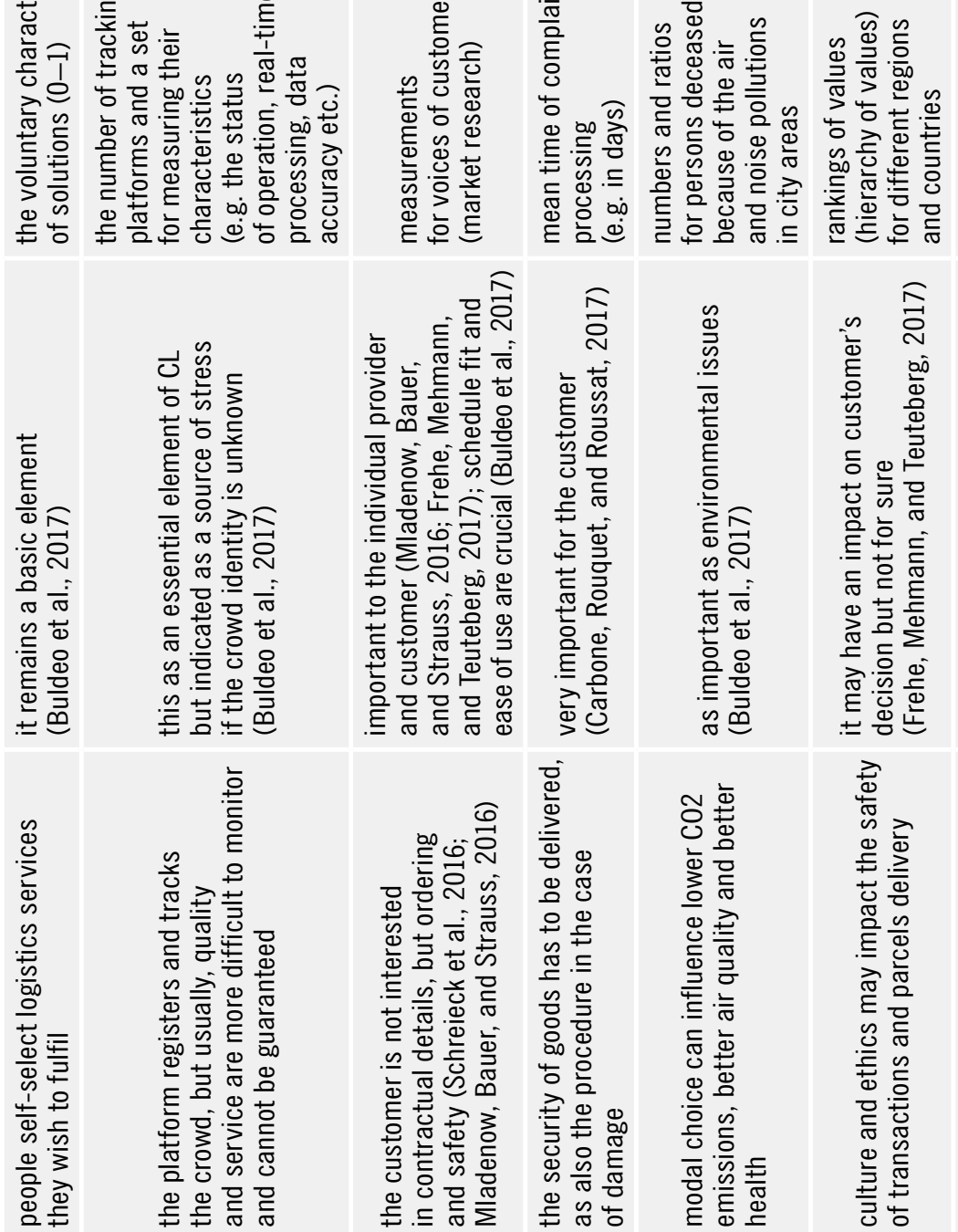

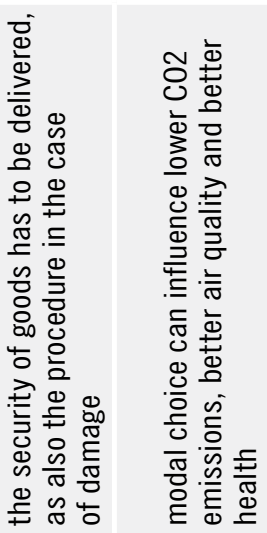
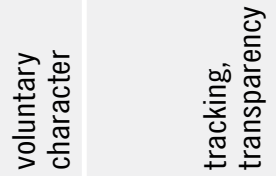

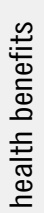

$\simeq$

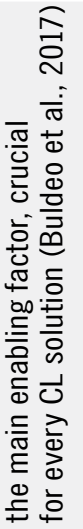

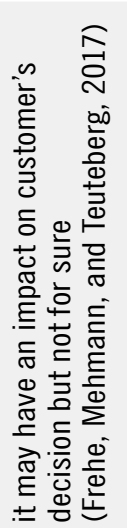

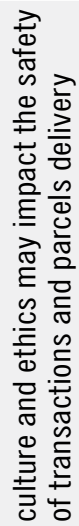
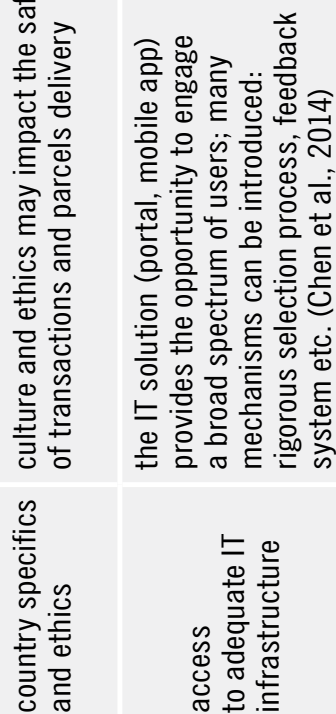

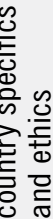

m

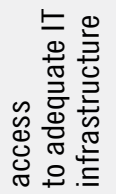

ذ 


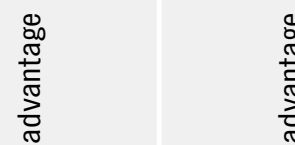

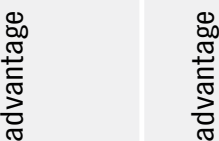

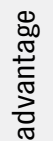

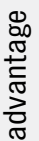

.

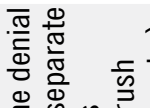
记芒总

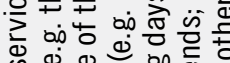

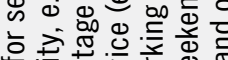

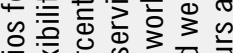

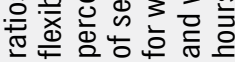

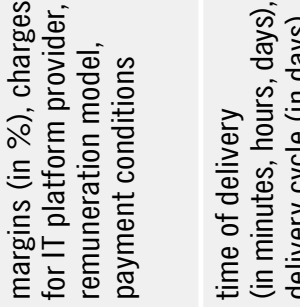

离

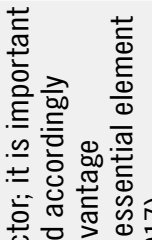

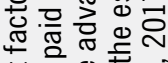

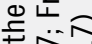

흐윰ำ

武京赔

당

를

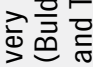

满落.

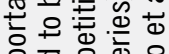

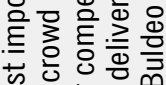

药

E

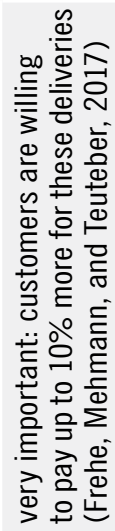

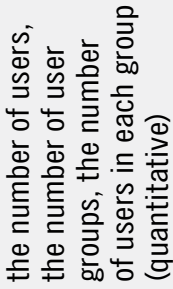

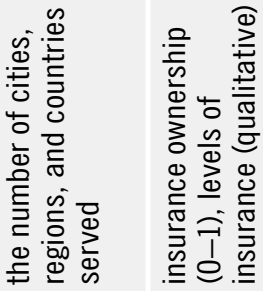

章 。

这

진

o

은 은

흔흥ㅎㅎㅇ

들요

ᄃ

흡 올

的言

U)

这耐

导就证要范

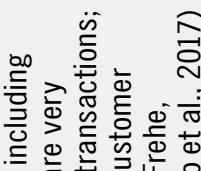

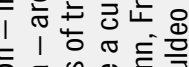

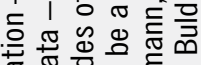

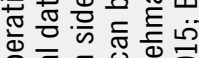

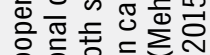

论

to

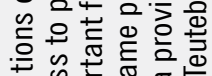

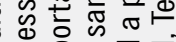

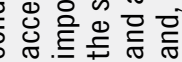

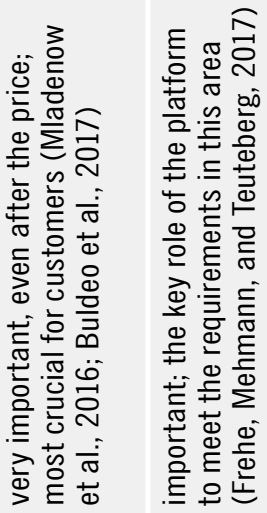

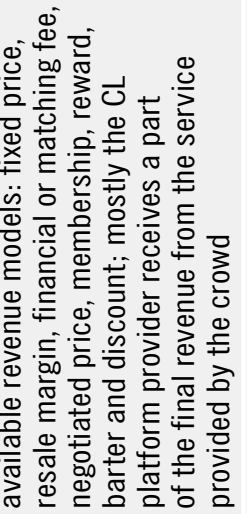

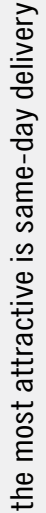
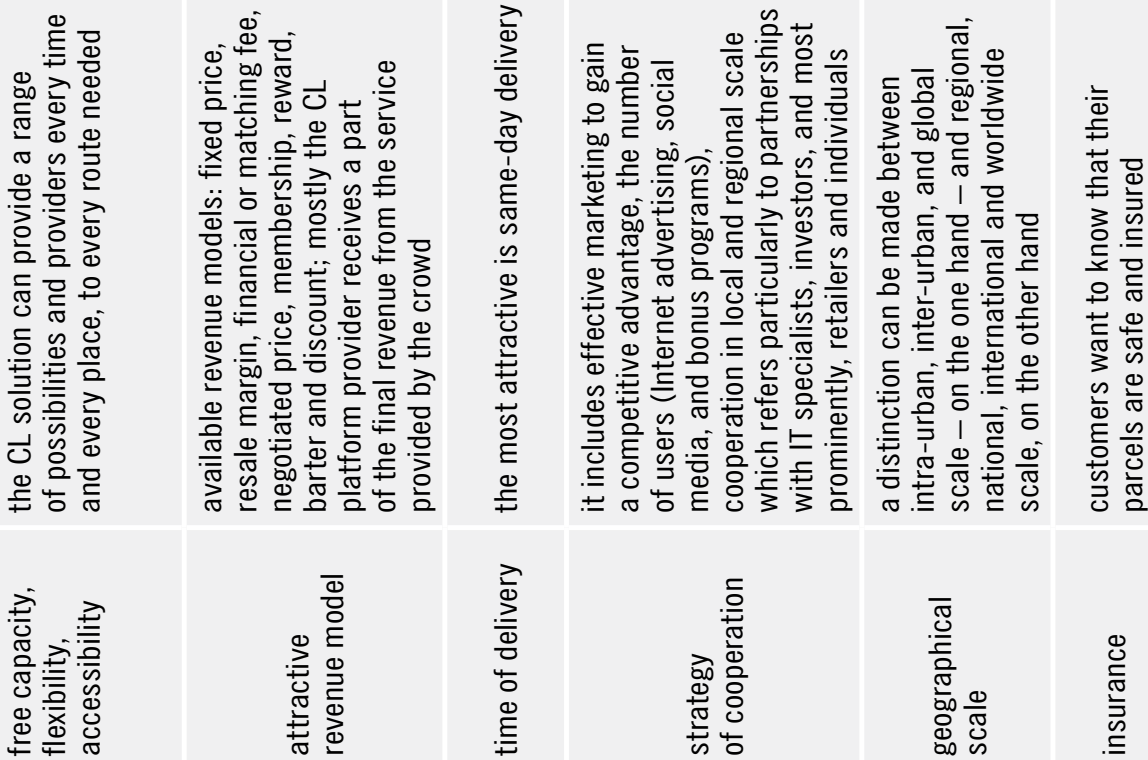

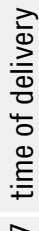

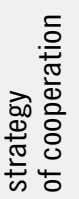

त্তু

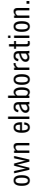

$\stackrel{\circ}{\sim}$

$\varphi$

$\infty$

9

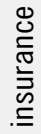

요

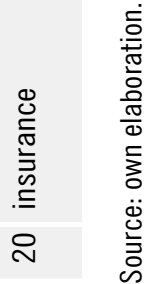


method for MDCM in logistics, which is what revealed the AHP to have the highest score in this regard. Moreover, the AHP was used many times for sustainable urban mobility planning (SUMP) analyses and SUMP-related problem-solving (19,000 results in Google Scholar; for ELECTRE ca. 9000, for PROMETHEE 4500, for TOPSIS 9600, for DEMATEL 2900). The popularity of this method means that its use in practice will be more likely than other methods, similarly to the knowledge of this method by people who can potentially use it. This approach will be most useful for customers, who in many cases also are urban or suburban residents. In some areas, the AHP method can also be a reference point for other CL stakeholders like local authorities, who must consider the attractiveness of CL solutions for people who live in the city or for other city users (e.g. business travelers).

The characteristics of customers' demand necessitated the choice of a method that would allow for combining the qualitative and quantitative criteria in a single calculation for assessment criteria. Because of its popularity, the classic AHP - introduced to social sciences in 1980s by R. W. Saaty (Saaty, 1987) - was a good choice. The AHP method has been used, e.g., to analyze the needs of CL stakeholders and assess market service providers (Abdul-Rahman et al., 2016).

Table 2. The AHP research procedure

\begin{tabular}{|c|l|}
\hline No. of step & \multicolumn{1}{c|}{ Description } \\
\hline 1 & Define the problem. \\
\hline 2 & Develop criteria framework. \\
\hline 3 & Construct pairwise comparison matrix for the criteria. \\
\hline 4 & Perform judgement for pairwise comparisons. \\
\hline 5 & Synthesize pairwise comparisons. \\
\hline 6 & Develop the criteria matrix. \\
\hline 7 & Perform steps (3-6) for all solutions/alternatives. \\
\hline 8 & Develop an overall ranking. \\
\hline 9 & Identify best solution. \\
\hline
\end{tabular}

Source: own elaboration.

According to the rules of the AHP method, establishing the final matrix requires calculating two matrices: first for the criteria and second for the values of the assessed solutions. In this study, we set only the first matrix, so from all the AHP steps presented in 
Table 2, we performed steps 1-6. If two criteria had the same value for the customer according to the results of the literature review - the relation between them was assessed as 1 ; if the first was more important, it received the value of $3,5,7$, or 9, depending on their importance. Then, the second solution compared to the first one respectively received the value of $1 / 3,1 / 5,1 / 7$, or $1 / 9$. In the next step, the criteria assessment matrix was normalized (see Table 3).

\section{Research Results}

The goal of this research is to build the ranking of criteria for assessing CL solutions according to the economic, social, and environmental sustainability dimensions. The criteria were prioritized to facilitate the choice of the best crowd logistics solution.

The characteristics mentioned as important for users of CL solutions (customers; see Appendix 1) can be divided into those related to advantages (criteria 1-6, 7, 10, 12; 15-19) and barriers (criteria $8,9,11,13,14,20$ ) of CL development. After implementing results of criteria assessment and building the ranking based on the AHP approach, we could build the ranking of their importance to customers (see Table 3), which - according to the idea of $\mathrm{CL}$ - can be also the service provider, no matter if he is a business provider or an individual.

Table 3. The ranking of criteria importance

\begin{tabular}{|c|c|c|c|c|c|}
\hline No. & Weight & Rank & No. & Weight & Rank \\
\hline 1 & 0.012294 & $13-20$ & 11 & $\mathbf{0 . 0 9 9 5 0 3}$ & $\mathbf{2}-\mathbf{6}$ \\
\hline 2 & 0.012294 & $13-20$ & 12 & 0.012294 & $13-20$ \\
\hline 3 & 0.012294 & $13-20$ & 13 & 0.012294 & $13-20$ \\
\hline 4 & 0.012294 & $13-20$ & 14 & $\mathbf{0 . 0 9 9 5 0 3}$ & $\mathbf{2 - 6}$ \\
\hline 5 & 0.012294 & $13-20$ & 15 & $\mathbf{0 . 0 9 9 5 0 3}$ & $\mathbf{2 - 6}$ \\
\hline $\mathbf{6}$ & 0.012294 & $13-20$ & 16 & $\mathbf{0 . 1 8 1 7 8 1}$ & $\mathbf{1}$ \\
\hline $\mathbf{8}$ & 0.028321 & $9-12$ & 17 & $\mathbf{0 . 0 9 9 5 0 3}$ & $\mathbf{2 - 6}$ \\
\hline 10 & 0.028321 & $9-12$ & 18 & $\mathbf{0 . 0 9 9 5 0 3}$ & $\mathbf{2 - 6}$ \\
\hline
\end{tabular}

Source: own elaboration. 
The results clearly show the domination of economic criteria (described as 14-20) over environmental (1-6) and social criteria (7-13). In fact, environmental sustainability was the least important for the customers in the analyzed literature. The weight assigned to criteria with a value close to 0.1 can be observed in the case of safety, access to adequate infrastructure, flexibility (accessibility), time of delivery, strategy of cooperation, and - unsurprisingly -revenue model, highly correlated with the price of services offered by the CL solution and the model of provisioning the CL platform provider (mediator). The revenue model received higher weight in the assessment and is responsible for almost $20 \%$ of the final grading of the chosen solution. The most attractive price - in most of the cases it is the lowest price - will be the most critical factor for customers when choosing a CL provider. Moreover, the time of delivery is important, especially when thinking of same-day delivery offer, for which customers are willing to pay more compared with the standard price list. Another advantage of the CL solutions is the accessibility and flexibility of the CL offers. The customer can find the best solution for the chosen route, parcel, and time of delivery. The strategy of cooperation is related to flexibility, but also to the revenue model. Customers are aware that they can also be service providers, and the possibility of balancing both kinds of their transactions is very important to them, and easy thanks to one contract or agreement to sign.

Barriers in the development of CL are also viewed as important for customers. Those are safety and access to adequate IT infrastructure. Customers perceive as important the safety of transaction - because it is related to the billing process and responsibility for damages within the delivery process - the safety of personal data, mostly processed in big data analysis, and matching offers to their requirements. There are many obstacles in handling data and securing safety for customers, so that strict procedures should be implemented to achieve and share data. A related issue is access to reliable and adequate IT infrastructure, which is a huge challenge for CL providers and one with a very complex nature, including data search, registering, data acquisition, and billing models.

\section{Conclusion}

This paper contains a proposition of the tool that enables assessing CL solutions based on the current literature and widely used methods in decision-making processes. According to our knowledge, this study is one of the first to evaluate this kind of sharing economy services. Thus, comparing the research results with existing literature is not easy, mainly because of treating sustainability as a whole, without a detailed analysis of the three sustainability criteria. Despite the fact of this research's novelty, some partial research results similar to those presented above can be found in the literature. These correspond 
with the results presented in other scientific papers from the studied area. One of them is environmental sustainability that is assessed as the least important for the customers (Mladenow et al., 2016; Carbone et al., 2018) in comparison to the economic one (Buldeo et al., 2017).

Despite the value of the research results and their contribution to the knowledge about the CL concept, this study has a few limitations. There is a risk of omitting valuable literature sources within the criteria identification process, although it should be noted that there is very little empirical research on CL solutions. Moreover, little research is based on customers' opinions, mostly due to the young age of CL solutions on the global market. Hence, future research should focus on evaluating existing CL solutions and customers to provide insight into real market needs. We hope this tool will be helpful in research processes of other scientists interested in the same area.

\section{References}

Abdul-Rahman, H., Wang C., Wood, L.C., and Ebrahimi, M. (2016). Integrating and Ranking Sustainability Criteria for Housing. Proceedings of the Institution of Civil Engineers - Engineering Sustainability, 169(1), 3-30. https://doi.org/10.1680/ensu.15.00008.

Afuah, A. and Tucci, C.L. (2013). Value Capture and Crowdsourcing. Academy of Management Review, 38(3), 457-460. https://doi.org/10.5465/amr.2012.0423.

Babbage, C. (1832). On the Economy of Machinery and Manufactures. Ldn.Knight. https://doi.org/10.5479/sil.975430.39088015716483.

Buys, L., Barnett, K.R., Miller, E. and Bailey, C. (2005). Smart housing and social sustainability: Learning from the residents of Queensland's Research House. Australian Journal of Emerging Technologies and Society, 31, 43-57.

Botsman, R. (2013). The rise of sharing economy. https://www.economist.com/leaders/2013/03/09/the-rise-of-the-sharing-economy.

Buldeo Rai, H., Verlinde, S., Merck, J. and Macharis, C. (2017). Crowd logistics: an opportunity for more sustainable urban freight transport? European Transport Research Review , 9, 1-13. https://doi.org/10.1007/s12544-017-0256-6.

Buldeo Rai, H., Verlinde, S.J. and Macharis, C. (2018). Shipping outside the box. Environmental impact and stakeholder analysis of a crowd logistics platform in Belgium. Journal of Cleaner Production, 202. https://doi.org/10.1016/j.jclepro.2018.08.210.

Carbone, V., Rouquet, A. and Roussat, C. (2018). A typology of logistics at work in Collaborative consumption. International Journal of Phisical Distribution \& Logistics Management, 48(6), 379-396. https://doi.org/10.1108/IJPDLM-11-2017-0355.

Carbone, V., Rouquet, A. and Roussat, C. (2017). The Rise of Crowd Logistics: A New Way to Co-Create Logistics Value. Journal of Business Logistics, 38(4), 238-252. https://doi.org/10.1111/jbl.12164.

Carbone, V., Rouquet, A. and Roussat, C. (2016). Carried out by the crowd: what types of logistics characterise collaborative consumption, https://www.piggybee.com/upload/press/UniversiteitUtrecht.pdf. 
Cheba, K. and Saniuk, S. (2016). Sustainable Urban Transport - The Concept of Measurement in the Field of City Logistics. Transportation Research Procedia, 16, 35-45. https://doi.org/10.1016/j.trpro.2016.11.005.

Chen, C., Cheng, S.F., Gunawan, A., Misra, A., Dasgupta, K., and Chander, D. (2014). TRACCS: Trajectory-Aware Coordinated Urban Crowd-Sourcing. Paper presented at the Second AAAI Conference on Human Computation and Crowdsourcing (HCOMP-14), November 3-4, Pittsburgh.

Dassen, T., Kunseler, E., and Kessenich, L.M. (2013). The Sustainable City: An Analytical-Deliberative Approach to Assess Policy in the Context of Sustainable Urban Development”. Sustainable Development, 21(3), 193-205. https://doi.org/10.1002/sd.1550.

Devari, A., Nikolaev, A.G. and He, Q. (2017). Crowdsourcing the last mile delivery of online orders by exploiting the social networks of retail store customers. Transportation Research Part $E$ Logistics and Transportation Review, 105, 105-122. https://doi.org/10.1016/j.tre.2017.06.011.

DHL Trend Research (2017). Sharing economy logistics: Rethinking logistics with access over ownership. DHL Trend Research. https://tinyurl.com/y7z6w628.

Ding, GKC. (2005). Developing a multicriteria approach for the measurement of sustainable performance. Building Research \& Information, 33(1), 3-16. https://doi.org/10.1080/0961321042000322618.

Doan, A., Ramakrishnan, R., and Halevy, A.Y. (2011). Crowdsourcing systems on the world-wide web. Communications of the ACM, 54(4), 86-89. https://doi.org/10.1145/1924421.1924442.

Drexhage, J. and Murphy, D. (2010). Sustainable Development: From Brundtland to Rio 2012. New York: International Institute for Sustainable Development.

Eckhardt, G.M. and Bardhi, F. (2015). The Sharing Economy Isn't About Sharing at All. Harvard Business Review, 28th January.

Ekins, P. (2011). Environmental sustainability: From environmental valuation to the sustainability gap. Progress in Physical Geography: Earth and Development. https://doi.org/10.1177/0309133311423186.

Finck, M. and Ranchordás, S. (2016). Sharing and the City. Vanderbilt Journal of Transnational Law, 49, 1299-1369. https://doi.org/10.2139/ssrn.2741575.

Frehe, V., Mehmann, J., and Teuteberg, F. (2017). Understanding and Assessing Crowd Logistics Business Models - Using Everyday People for Last Mile Delivery. Journal of Business and Industrial Marketing, 32(1), 75-97. https://doi.org/10.1108/JBIM-10-2015-0182.

Frenken, K. and Schor, J. (2017). Putting the sharing economy into perspective. Environmental Innovation and Societal Transitions, 23, 3-10. https://doi.org/10.1016/j.eist.2017.01.003.

Geron, T. (2013). Airnbn and unstoppable rise of the share economy. Forbes, 23 January.

Gonzalez-Feliu, J., Pronello, C. and Salanova Grau, J.M. (2018). Multi-Stakeholder Collaboration in Urban Transport: State-of-the-Art and Research Opportunities. Transport, 33, 1079-1094. https:// doi.org/10.3846/transport.2018.6810.

Hamari, J., Sjoklint, M. and Ukkonen, A. (2016). The sharing economy: Why people participate in collaborative consumption. Journal of the Association for Information Science and Technology, 67(9), 2047-2059. https://doi.org/10.1002/asi.23552.

Han, J. and Hayashi, Y. (2008). A system dynamics model of CO2 mitigation in China's intercity passenger transport. Transportation Research Part D: Transport and Environment, 13(5), 298-305. https://doi.org/10.1016/j.trd.2008.03.005.

Hopwood, B., Mellor, M., and O’Brien, G. (2005). Sustainable development: mapping different approaches. Sustainable Development, 13(1), 38-52. https://doi.org/10.1002/sd.244.

Howe, J. (2006). The rise of crowdsourcing. Wired. https://www.wired.com/2006/06/ crowds/. 
Kafle, N., Zou, B., and Lin, J. (2017). Design and modeling of a crowdsource-enabled system for urban parcel relay and delivery. Transportation Research Part B: Methodological, 99, 62-82. https://doi.org/10.1016/j.trb.2016.12.022.

Keeble, B.R. (1988). The Brundtland Report: “Our Common Future”. Medicine and War, 4. https://doi.org/10.1080/07488008808408783.

Li, Z. and Hensher D.A. (2013). Crowding in Public Transport: A Review of Objective and Subjective Measures. Journal of Public Transportation, 16(2), 107-134. https://doi.org/10.5038/2375-0901.16.2.6.

Macharis, C. (2018). Shipping outside the box. Environmental impact and stakeholder analysis of a crowd logistics platform in Belgium. Journal of Cleaner Production, 202, 806-816. https://doi.org/10.1016/j.jclepro.2018.08.210.

Marcucci, E., Le Pira, M., Carrocci, C.S., Gatta, V., and Pieralice, E. (2017). Connected shared mobility for passengers and freight: Investigating the potential of crowdshipping in urban areas. Proceedings of 2017 5th IEEE International Conference on Models and Technologies for Intelligent Transportation Systems (MT-ITS), Naples, Italy, 26-28 June 2017, 839-843. https://doi.org/10.1109/MTITS.2017.8005629.

Mehmann, J., Frehe, V., and Teuteber, F. (2015). Crowd logistics - a literature review and maturity model. Proceedings of the Hamburg international conference of logistics. Hamburg.

Mladenow, A., Bauer, C., and Strauss, C. (2016). Crowd logistics - the contribution of social crowd in logistics activities. International Journal of Web Information System, 12(3), 379-396. https://doi.org/10.1108/IJWIS-04-2016-0020.

Moldan, B., Janoušková, S. and Hák, T. (2012). How to understand and measure environmental sustainability: Indicators and targets. Ecological Indicators, 17, 3-14. https://doi.org/10.1016/j.ecolind.2011.04.033.

Morelli, J. (2011). Environmental Sustainability: A Definition for Environmental Professionals. Journal of Environmental Sustainability, 1. https://doi.org/10.14448/jes.01.0002.

Paloheimo, H., Lettenmeier, M., and Waris, H. (2016). Transport reduction by crowdsourced deliveries-a library case 857 in Finland. Journal of Cleaner Production, 132, 240-251. https://doi.org/10.1016/j.jclepro.2015.04.103.

Poetz, M.K. and Schreier, M. (2012). The value of crowdsourcing: can users really compete with professionals in generating new product ideas? Journal of Product Innovation Management, 29(2), 245-256. https://doi.org/10.1111/j.1540-5885.2011.00893.x.

Priester, R., Miramontes, M., and Wulfhorst, G. (2014). A Generic Code of Urban Mobility: How can Cities Drive Future Sustainable Development? Transportation Research Procedia, 4, 90-102. https://doi.org/10.1016/j.trpro.2014.11.008.

Primentel, C. and Alvelos, F. (2018). Integrated urban freight logistics combining passenger and freight flows - mathematical proposal model. Transportation Research Procedia, 30, 80-89. https://doi.org/10.1016/j.trpro.2018.09.010.

Rougčs, J.F. and Montreuil, B. (2014). Crowdsourcing delivery: New interconnected business models to reinvent delivery. Proceedings of 1st International Physical Internet Conference, Quebec City, Canada, 28-30 May 2014.

Saaty, R.W. (1987). The Analytic Hierarchy Process - what it is and how it is used. Mathematical Modelling, 9(3), 161-176. https://doi.org/10.1016/0270-0255(87)90473-8.

Sampaio, A., Savelsbergh, M., Veelenturf, L., and van Woensel, T. (2019). Crowd-Based City Logistics. Sustainable Transportation and Smart Logistics, 381-400.

https://doi.org/10.1016/B978-0-12-814242-4.00015-6. 
Sampaio, A., Savelsbergh, M., Veelenturf, L., and Van Woensel, T. (2017). Crowd-based City Logistics. SCL Report Series Crowd-based City Logistics.

Schor, J.B. (2014). Debating the Sharing Economy Great Transition Initiative. Journal of Self-Governance \& Management Economics, 4.

Serafini, S., Nigro, M., Gatta, V., and Marcucci, E. (2018). Sustainable crowdshipping using public transport: A case study evaluation in Rome. Transportation Research Procedia, 30, 101-110. https://doi.org/10.1016/j.trpro.2018.09.012.

Tranfield, D., Denyer, D., and Smart, P. (2003). Towards a Methodology for Developing Evidence: Informed Management Knowledge by Means of Systematic Review. British Journal of Management, 14, 207-222. http://dx.doi.org/10.1111/1467-8551.00375.

United Nations (2014). World Urbanization Prospects. Economic and Social Affairs. https://www.compassion.com/multimedia/world-urbanization-prospects.pdf.

Un-Habitat (2013). Planning and Design for Sustainable Urban Mobility. https://doi.org/10.4324/9781315857152.

Valiantis, M. (2014). Sustainable urban transport. In: Sustainability behind Sustainability. Nova Publishers.

Wang, Y., Zhang, D., Liu, Q., Shen, F., and Lee, L.H. (2016). Towards enhancing the last-mile delivery: An effective crowd-tasking model with scalable solutions. Transportation Research Part E, 93, 279-293. https://doi.org/10.1016/j.tre.2016.06.002.

World Conservation Strategy - Living Resource Conservation for Sustainable Development. (1980). International Union for Conservation of Nature and Natual Resources (IUCN). 


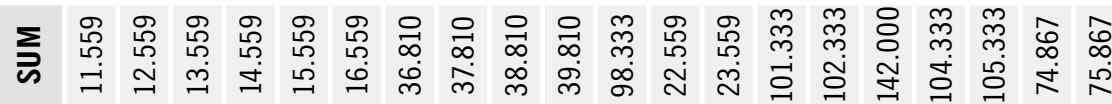

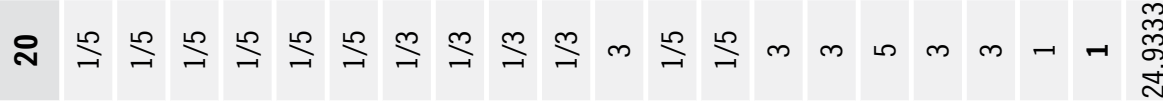

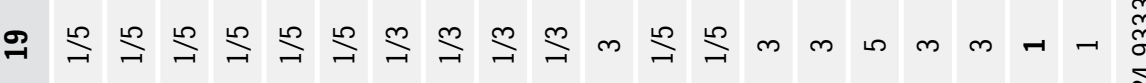

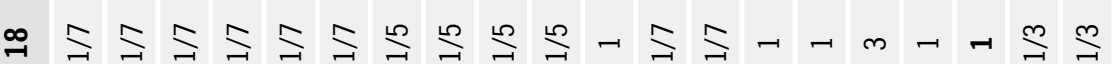

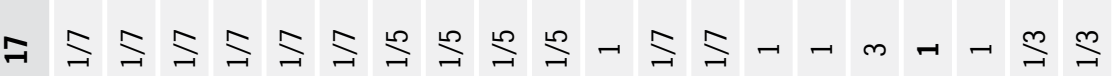

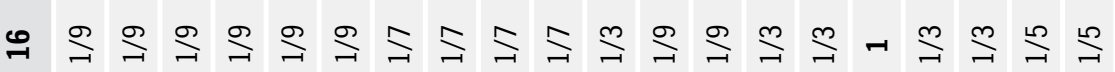
n

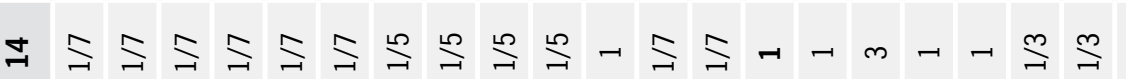

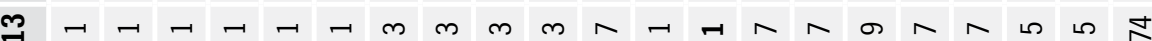

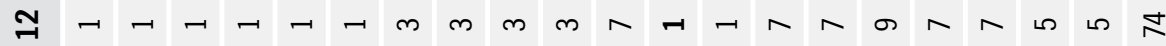

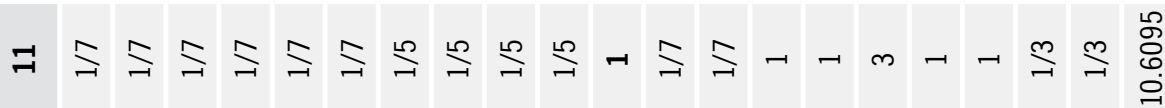
을 ๓

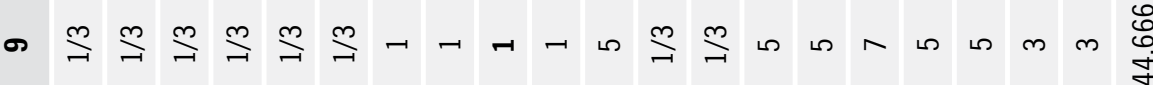

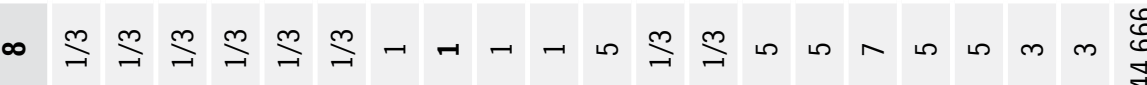

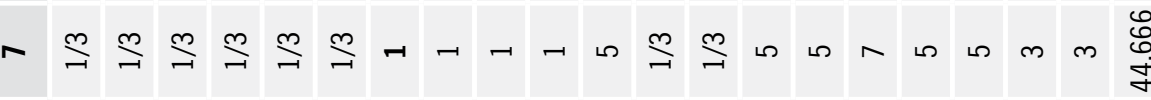
. 产

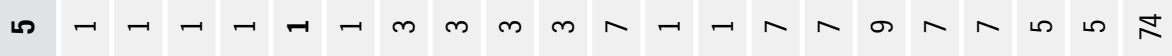

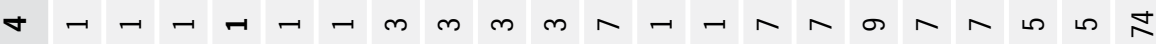

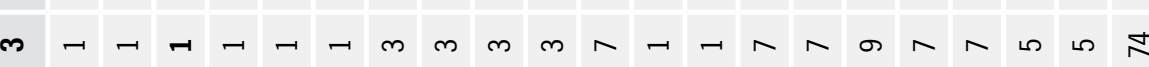

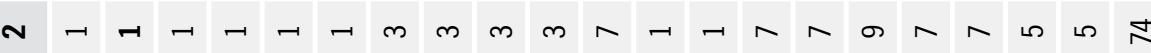

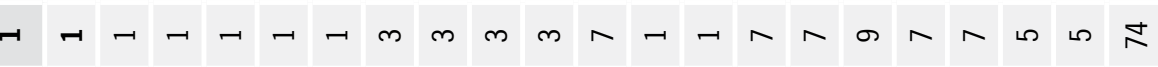

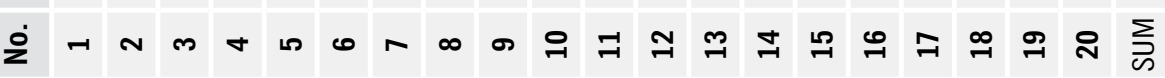

